ANDRZEJ PODRAZA

Katolicki Uniwersytet Lubelski Jana Pawła II

ORCID: 0000-0002-8181-6612

e-mail: andrzej.podraza@kul.pl

\title{
Bezpieczeństwo energetyczne Polski
} w kontekście neoimperialnej polityki Rosji oraz współpracy europejskiej i transatlantyckiej: Polska jako hub gazowy

Poland's energy security in the context of Russia's neo-imperial policy as well as European and transatlantic cooperation: Poland as a gas hub

Słowa kluczowe:

bezpieczeństwo energetyczne, strategia gazowa Polski, hub gazowy, Inicjatywa Trójmorza, neoimperialna polityka Rosji, Nord Stream II, USA, Unia Europejska
Keywords:

energy security,

Poland's gas strategy, gas hub, Three Seas Initiative, Russia's neo-imperial policy, Nord Stream II, USA, European Union 


\section{Poland's energy security in the context of Russia's neo-imperial policy as well as European and transatlantic cooperation: Poland as a gas hub}

The aim of the article is to analyse Poland's energy security in the context of Russia's neo-imperial policy, treating energy carriers as an instrument of influence and dependence of states, and to rebuild its international position. In line with the geopolitical approach, limiting the energy dependence of Central and Eastern Europe on Russia has not only a purely economic dimension, but concerns the geostrategic future of the European continent and the type of international order to be developed in Europe and in the transatlantic area. Poland's gas strategy is a case study. Poland decided to finish the contract for the purchase of natural gas from Russia by December 31, 2022. Poland, striving to meet the growing needs for natural gas, undertakes actions aimed at diversifying sources and directions of supplies. Particular emphasis is placed on the concept of Poland as a gas hub developed within the framework of the Three Seas Initiative and a desire to prevent Russia and Germany from building the Nord Stream II pipeline, a project, which is in Poland's opinion, contradictory with the aim to ensure Europe's energy security. 


\section{Wstęp}

D ezpieczeństwo energetyczne jest współcześnie bardzo dynamiczną koncepcją, która swoim zakresem obejmuje wiele różnych zagadnień, jakkolwiek jej geopolityczny i geoekonomiczny wymiar jest nadal aktualny. Jak zauważył w 1990 r. Edward Luttwak, zakończenie zimnej wojny doprowadziło do pomniejszenia znaczenia siły militarnej na rzecz geoekonomicznej ${ }^{1}$. W takim ujęciu geoekonomia rozumiana jest jako wykorzystywanie narzędzi ekonomicznych do realizacji celów geopolitycznych, jest więc połączeniem ekonomii międzynarodowej, geopolityki i strategii ${ }^{2}$. Podobnie jak w czasach Aten i Sparty państwa współzawodniczą ze sobą, ale współczesne konflikty i wojny toczą się często przy użyciu innych środków niż militarne, a inwazja Stanów Zjednoczonych na Irak w 2003 r. może być jednym z ostatnich przypadków agresji w tradycyjnym stylu ${ }^{3}$. Energię bez wątpienia można traktować jako instrument geoekonomiczny. Dla Federacji Rosyjskiej w XXI w. ropa naftowa i gaz ziemny nie są jedynie głównym źródłem dochodów budżetowych i znaczącym elementem kształtującym jej dochód narodowy. Rosja wykorzystuje te nośniki energii w polityce zagranicznej jako instrument nacisku politycznego na państwa sąsiedzkie i odbudowę imperialnej pozycji w stosunkach międzynarodowych. Jednocześnie nośniki energii mogą również stanowić źródło atrakcyjności gospodarczej dla partnerów nie tylko w najbliższym sąsiedztwie, ale przede wszystkim w Europie oraz w regionie Azji i Pacyfiku.

Głównym celem artykułu jest analiza bezpieczeństwa energetycznego Polski oraz Europy Środkowej w kontekście rozwoju współpracy transatlantyckiej i europejskiej w tym zakresie z uwagi na neoimperialną politykę

1 E. N. Luttwak, From geopolitics to geo-economics: logic of conflict, grammar of commerce, „The National Interest” 1990, issue 20, s. 17-23.

2 Robert Blackwill i Jennifer Harris, autorzy książki na temat „wojny w inny sposób”, następująco definiują geoekonomię: „Wykorzystanie instrumentów ekonomicznych do promowania i obrony interesów narodowych oraz do uzyskiwania korzystnych wyników geopolitycznych; oraz wpływ działań gospodarczych innych narodów na cele geopolityczne państwa" (R. Blackwill, J. Harris, War by other means. Geoeconomics and statecraft, Harvard University Press, Cambridge Mass., Harvard 2016, s. 20).

3 K. J. Holsti, The decline of international politics as an academic discipline: can it be saved?, "Global Affairs" 2019, vol. 5, issue 4-5, s. 5. 
prowadzoną przez Federację Rosyjską, która traktuje nośniki energii jako istotny instrument wpływu i uzależnienia oraz odbudowy pozycji na arenie międzynarodowej. Bezpieczeństwo energetyczne Polski ma charakter geopolityczny, co wynika z kompleksowego charakteru tej koncepcji na przełomie XX i XXI w., uwarunkowanej przez połączone ze sobą zróżnicowane problemy o charakterze politycznym, geograficznym, gospodarczym i technologicznym. Geopolityka warunkuje strategię Polski w zakresie zapewnienia bezpieczeństwa energetycznego i ograniczenia jednocześnie zależności od Rosji. Wpływa także na zakres i charakter współpracy w ramach Unii Europejskiej i w wymiarze transatlantyckim ze szczególnym uwzględnieniem Stanów Zjednoczonych. W takim ujęciu Europa Środkowa, ale także szerzej Europa, traktowana jest jako obszar starcia zróżnicowanych interesów, gdzie dążenie do ograniczenia zależności energetycznej od Rosji nie ma jedynie wymiaru czysto gospodarczego, ale dotyczy geostrategicznej przyszłości kontynentu europejskiego i charakteru rozwijanego w Europie oraz $\mathrm{w}$ przestrzeni transatlantyckiej porządku międzynarodowego, dla stabilności którego wyzwaniem jest polityka realizowana przez rewizjonistyczną potęgę, jaką jest Rosja Władimira Putina. Takie zagadnienia jak: budowa rurociągu Nord Stream II, dywersyfikacja źródeł energii oraz dostęp Stanów Zjednoczonych do europejskiego rynku gazu, współpraca między USA a Unią Europejską w zakresie handlu energią i bezpieczeństwa dostaw, amerykańska Inicjatywa Partnerstwa na rzecz Transatlantyckiej Współpracy Energetycznej, rola NATO w działaniach na rzecz ochrony energetycznej infrastruktury krytycznej, współpraca energetyczna w ramach Inicjatywy Trójmorza oraz koncepcja Polski jako hubu gazowego, mieszczą się w ramach rywalizacji strategicznej i mogą przesądzić nie tylko o tempie rozwoju gospodarczego poszczególnych państw europejskich, ale także o charakterze porządku międzynarodowego w XXI w. W artykule niniejszym strategia gazowa Polski w kontekście międzynarodowym będzie traktowana jako studium przypadku zapewnienia bezpieczeństwa energetycznego.

\section{Surowce energetyczne jako instrument polityki zagranicznej Federacji Rosyjskiej}

Rewizjonizm Federacji Rosyjskiej stanowi bezpośrednie zagrożenie dla wielu państw Europy Środkowej oraz Wschodniej, a także jest znaczącym 
wyzwaniem dla Unii Europejskiej, Stanów Zjednoczonych i NATO. Przejawia się on w różnych wymiarach rywalizacji strategicznej, tj. przede wszystkim politycznym, militarnym, gospodarczym, ale również w odniesieniu do cyberprzestrzeni lub przede wszystkim do surowców energetycznych. Przyczyny rewizjonizmu rosyjskiego są zróżnicowane, począwszy od poczucia wykluczenia z europejskiego systemu bezpieczeństwa, poprzez nostalgię za utraconym imperium i dążenie do odbudowy pozycji Rosji jako potęgi globalnej. Ale na stanowisko Rosji wpływ mają także czynniki wewnętrzne, które rzutują na strategię międzynarodową, takie jak chęć przetrwania reżimu Władimira Putina oraz ograniczona transformacja polityczna i gospodarcza Rosji. Rywalizacja strategiczna dotyczy przede wszystkim tzw. wspólnego sąsiedztwa Europy i Rosji. Jednak dla Rosji bardzo ważnym obszarem jest nadal cała Europa Środkowa i Wschodnia, mimo że większość państw tego regionu obecnie wchodzi w skład Unii Europejskiej i Sojuszu Północnoatlantyckiego. Po zakończeniu zimnej wojny Europa Środkowa i Wschodnia jest istotnym obszarem strategicznej rywalizacji mocarstw jako elementu współzawodnictwa w Europie z uwagi na kluczowe geograficzne umiejscowienie pomiędzy Europą a Azją. Kontrola nad tym obszarem może stanowić punkt wyjścia do dalszej penetracji i podporządkowania sobie Eurazji, a wykorzystanie nośników energiii przez Rosję ma na celu uzależnienie poszczególnych państw i rozszerzenie mniej lub bardziej formalnie własnej strefy wpływów. Rywalizację energetyczną można więc nazwać konfliktem przy zastosowaniu innych środków, w którym celem Rosji jest stopniowa destabilizacja państw Europy Środkowej i Wschodniej.

Obecnie wyróżniamy trzy główne perspektywy analizy stanowiska Rosji wobec istniejącego porządku międzynarodowego ${ }^{4}$. Po pierwsze, Rosja może być traktowana jako „potęga rewanżystowska” zmierzająca do obalenia samych fundamentów liberalnego porządku światowego. W drugim podejściu Rosja jest uważana za "potęgę obronną", gdyż jej celem jest przeprowadzenie stopniowych zmian istniejącego porządku międzynarodowego. Po trzecie, Rosja może być nazywana "agresywnym izolacjonistą", co oznacza, że reżim Putina dąży do wzmocnienia swojej wewnętrznej

4 E. Götz, C. R. Merlen, Russia and the question of world order, „European Politics and Society" 2019, vol. 20, issue 2, s. 133. 
legitymizacji poprzez ochronę Rosji przed wpływami Zachodu 5 . Bez względu na przyjęcie konkretnej perspektywy analiz należałoby odpowiedzieć na pytanie o motywacje akceptacji przez elity kremlowskie określonego sposobu działania na arenie międzynarodowej. Jakkolwiek można wymienić różnorodne czynniki wpływające na politykę Rosji, to jednak należy przyjąć tezę, że zasadniczym uzasadnieniem jest dążenie do przetrwania Władimira Putina jako przywódcy Rosji i jego skorumpowanego reżimu. Neoimperialna polityka Rosji, której wyrazem jest przede wszystkim agresja na Ukrainie i aneksja Krymu w 2014 r., może być traktowana jako nowe powstrzymywanie, gdyż jej celem jest przeciwdziałanie różnym inicjatywom Zachodu na terenie wspólnego sąsiedztwa, m.in. Partnerstwu Wschodniemu Unii Europejskiej ${ }^{6}$. Rosja obawia się konsolidacji demokracji i systemu gospodarki rynkowej w państwach na obszarze poradzieckim, gdyż mogłoby to skutkować eksportem tzw. kolorowej rewolucji do Rosji i ostatecznie zachwianiem podstawami reżimu Władimira Putina. Ma z tym także związek nostalgia Putina za utraconym imperium, gdyż bardzo mocno podkreśla on, że rozpad Związku Sowieckiego był największą katastrofą geopolityczną XX w. Dążenie do kontynuacji polityki kolonizacji państw sąsiedzkich, którą Rosja prowadziła od wieków, to droga do odmowy uznania pełnej suwerenności państw powstałych w wyniku rozpadu Związku Sowieckiego w grudniu 1991 r., gdyż obszar ten traktowany jest jako wyłączna strefa wpływów Rosji. Potwierdzeniem tezy o niemalże osobistych źródłach działań Władimira Putina może być referendum konstytucyjne z przełomu czerwca i lipca 2020 r., które pozwala prezydentowi Rosji sprawować władzę aż do roku $2036^{7}$. Z pewnym uproszczeniem można wobec tego dojść do przekonania, że zarówno w polityce wewnętrznej, jak

5 Elias Götz i Camille-Renaud Merlen używają na określenie Rosji terminu „spoiler", który został wprowadzony w 1997 r. do teorii konfliktu przez Stephena Johna Stedmana. Twierdzi on, że spoiler to „przywódcy i partie, którzy wierzą, że pokój wyłaniający się z negocjacji zagraża ich władzy, światopoglądowi i interesom, i używają przemocy, aby podważyć próby osiągnięcia tego celu" (S. J. Stedman, Spoiler problems in peace processes, „International Security” 1997, vol. 22, issue 2, s. 5).

6 A. Podraza, Promocja demokracji a bezpieczeństwo europejskie: skuteczność $i$ dylematy polityki wschodniej Unii Europejskiej w XXI w., „Politeja” 2016, nr 2 (41), s. 168-172.

7 Zgodnie z oficjalnymi danymi zmiany zostały poparte przez niemal 78 proc. głosujących (Putin strongly backed in controversial Russian reform vote, BBC News [online], 2 VII 2020 [dostęp: 3 VII 2020], dostępny w internecie: <https://www.bbc.com/news/ world-europe-53255964>. 
i zagranicznej stosowane instrumenty mają służyć zapewnieniu przetrwania reżimu Putina, a pozostałe cele są temu podporządkowane.

W rosyjskiej strategii polityki zagranicznej, którą można opisywać $\mathrm{w}$ kategoriach neoimperialnych, wykorzystywane są w dużej mierze nośniki energii, przede wszystkim gaz ziemny, ale również ropa naftowa, które mają pozwolić Rosji na wywieranie wpływu przede wszystkim na państwa szerokiego sąsiedztwa. Są one elementami strategii, w której oprócz tradycyjnych instrumentów, takich jak zależność energetyczna, siła militarna czy też z zakresu soft power, Rosja dąży do tworzenia uzależnienia opartego na regułach reżimu instytucjonalnego na obszarze posowiec$\mathrm{kim}^{8}$. Prowadzi to do rywalizacji z takimi aktorami jak Stany Zjednoczone, NATO i Unia Europejska na terytorium wspólnego sąsiedztwa, jakkolwiek celem Rosji jest również energetyczne uzależnianie państw członkowskich Unii Europejskiej. Rosja deklaruje w swojej koncepcji polityki zagranicznej z 30 listopada 2016 r., że jej zadaniem strategicznym w stosunkach z Unią Europejską ,jest budowanie wspólnej przestrzeni gospodarczej i humanitarnej na obszarze od Atlantyku do Pacyfiku na bazie harmonizacji i sprzężenia procesów integracji europejskiej i euroazjatyckiej, co zapobiegnie pojawianiu się linii podziału na kontynencie europejskim"9.

Jednocześnie Rosja krytycznie podchodzi do działań państw zachodnich, które są oskarżane o dążenie do utrzymania swojej pozycji, narzucanie własnej wizji procesów globalnych i prowadzenie polityki powstrzymywania rozwoju alternatywnych ośrodków potęgi, co prowadzi do niestabilności w stosunkach międzynarodowych oraz wzmocnienia globalnych i regionalnych turbulencji. Rosja dąży więc do uzyskania statusu jednego z głównych graczy na arenie międzynarodowej, co po zakończeniu zimnej wojny nie byłoby możliwe bez posiadania znaczących zasobów energetycznych. Współcześnie to nie siła militarna, jak w okresie zimnej wojny, tylko przede wszystkim gaz ziemny i ropa naftowa decydują o pozycji międzynarodowej Rosji, lecz również o możliwościach jej wewnętrznego rozwoju gospodarczego.

8 A. Podraza, Promocja demokracji..., s. 171.

9 Foreign Policy Concept of the Russian Federation (approved by President of the Russian Federation Vladimir Putin on November 30, 2016), The Ministry of Foreign Affairs of the Russian Federation [online], 1 XII 2016 [dostęp: 10 VI 2020], dostępny w internecie: <https://www.mid.ru/en/foreign_policy/official_documents/-/asset_publisher/ CptickB6BZ29/content/id/2542248>. 
Nośniki energii były wykorzystywane do osiągania celów w polityce zagranicznej już w okresie Związku Sowieckiego. Ten sposób podejścia został sformalizowany w przyjętej w 1991 r. doktrynie FalinaKwiecińskiego, zgodnie z którą uzależnienie od dostaw surowców energetycznych z ZSRS, a później Rosji miało osłabić procesy integracyjne państw Europy Środkowej i Wschodniej ze strukturami europejskimi i atlantyckimi $^{10}$. Dojście Władimira Putina do władzy 31 grudnia 1999 r. doprowadziło do wzmocnienia polityki energetycznej Rosji w tym zakresie, gdyż zaczęto rozwijać strategię geoekonomiczną, której celem jest powiększenie własnej strefy wpływów, wzmocnienie sił odśrodkowych w Europie oraz osłabienie Unii Europejskiej ${ }^{11}$. Jak stwierdzono w Strategiii energetycznej Federacji Rosyjskiej do 2030 roku $^{12}$, zasoby energetyczne mają służyć osiąganiu określonych celów wewnętrznych, tj. maksymalizacji efektywnego wykorzystania naturalnych zasobów energii i potencjału sektora energetycznego do utrzymania wzrostu gospodarczego i poprawy jakości życia ludności, ale również zewnętrznych, tj. związanych z dążeniem do umocnienia zagranicznej pozycji gospodarczej Rosji ${ }^{13}$. Takie podejście jest widoczne również w innych dokumentach i ma wpływ na konkretne zewnętrzne działania Federacji Rosyjskiej. Można wobec tego dojść do wniosku, że współcześnie potęga Rosji w odróżnieniu od okresu zimnej wojny opiera się nie tyle na sile militarnej, ile na nośnikach energii, które są elastycznym narzędziem wpływów. Są one, po pierwsze, źródłem atrakcyjności gospodarczej dla sąsiadów i partnerów, a po drugie - istotnym czynnikiem w stosunkach dwustronnych z sąsiadami z uwagi na możliwość osiągania dzięki nim korzyści gospodarczych i politycznych, także wykorzystywania ich jako źródła przymusu, oraz po trzecie - sposobem na uzyskanie wpływów

10 M. Ruszel, Analiza wybranych nieformalnych sposobów wpływania na politykę energetyczna UE - na przykładzie Federacji Rosyjskiej, "Bezpieczeństwo Narodowe” 2015, nr 35, s. 114-115.

11 M. Wigell, A. Vihma, Geopolitics versus geoeconomics: the case of Russia's geostrategy and its effects on the EU, „International Affairs” 2016, vol. 92, issue 3, s. 610.

12 Rząd Rosji 2 kwietnia 2020 r. przyjął nową Strategię energetyczną Federacji Rosyjskiej do 2035 roku. (S. Kardaś, Nowa strategia energetyczna Rosji - optymistyczne plany w niepewnych czasach, 15 IV 2020, Ośrodek Studiów Wschodnich. Komentarze 325, s. 1).

13 Ministry of Energy of the Russian Federation, Energy strategy of Russia for the period up to 2030. Approved by Decree $N^{\circ}$ 1715-r of the Government of the Russian Federation dated 13 November 2009, Moscow 2010, s. 10. 
gospodarczych i politycznych poprzez nietradycyjne, a czasem nieprzejrzyste mechanizmy ${ }^{14}$. Taki sposób traktowania surowców energetycznych powoduje, że są one często wykorzystywane przez Rosję jako instrument nacisku politycznego i rozszerzania wpływów rosyjskich. Tak należy interpretować budowę rurociągów Nord Stream i Nord Stream II, których celem jest zwiększanie uzależnienia Niemiec i Europy od dostaw gazu z Rosji, ale przede wszystkim marginalizowanie Ukrainy i Białorusi, a także Polski jako państw tranzytowych. W ramach rosyjskiego szantażu politycznego i gospodarczego mieszczą się również przerwy w dostawach gazu lub groźba wstrzymania ich dostarczania do państw sąsiedzkich, jak chociażby miało to miejsce w odniesieniu do Ukrainy w 2009 i 2014 r.

\section{Strategia bezpieczeństwa energetycznego Polski w kontekście polityki Rosji}

Zgodnie z projektem Polityki energetycznej Polski do 2040 r. dywersyfikacja dostaw gazu i ropy oraz rozbudowa infrastruktury sieciowej stanowi jeden $\mathrm{z}$ podstawowych celów polityki państwa $\mathrm{w}$ zakresie bezpieczeństwa energetycznego ${ }^{15}$. Biorąc pod uwagę deklarację, że

celem polityki energetycznej państwa jest bezpieczeństwo energetyczne, przy zapewnieniu konkurencyjności gospodarki, efektywności energetycznej i zmniejszenia oddziaływania sektora energii na środowisko, przy optymalnym wykorzystaniu własnych zasobów energetycznych ${ }^{16}$,

można dojść do przekonania, iż u podstaw takiego sposobu myślenia leży nowoczesna definicja bezpieczeństwa energetycznego. Można przede wszystkim przytoczyć określenie przyjęte przez tokijskie Centrum Badań Energetycznych Azji i Pacyfiku z 2007 r., zgodnie z którym bezpieczeństwo energetyczne to:

14 J. Lough, Russia's energy diplomacy, Chatham House, London, v 2011 (Chatham House Briefing Paper), s. 2.

15 Zaktualizowany projekt polityki energetycznej Polski do 2040 r., Ministerstwo Gospodarki, Warszawa 2019, s. 11.

16 Tamże, s. 10. 
zdolność gospodarki do zagwarantowania dostępności dostaw zasobów energetycznych w sposób zrównoważony i terminowy z ceną energii na poziomie, który nie będzie miał niekorzystnego wpływu na wyniki ekonomiczne gospodarki ${ }^{17}$.

W definicji tej, oprócz klasycznych elementów, jakimi są dostępność nośników energii, ich przystępność cenowa, osiągalność m.in. z uwagi na czynniki geopolityczne i związane z inwestycjami infrastrukturalnymi, pojawiło się także w miarę nowe kryterium, tj. akceptowalności, biorąc pod uwagę skutki dla środowiska. Taki sposób myślenia prowadzi do wypracowania wszechstronnej strategii energetycznej, w której zasadniczym priorytetem jest uniezależnienie się z powodów politycznych od dostaw ropy naftowej i gazu ziemnego z Rosji z uwagi na sposób wykorzystania nośników energii przez Rosję. Działania Polski w wymiarze środkowoeuropejskim, europejskim, transatlantyckim, ale także w odniesieniu do Bliskiego Wschodu są wobec tego $\mathrm{w}$ dużej mierze podyktowane presją polityczną ze strony Rosji.

W kontekście polityki Federacji Rosyjskiej najważniejszym elementem strategii bezpieczeństwa energetycznego Polski są działania odnoszące się przede wszystkim do dostaw gazu ziemnego i ropy naftowej, gdyż popyt krajowy na te nośniki energii zapewniany jest przede wszystkim przez import. $\mathrm{W}$ przypadku gazu ziemnego potrzeby $\mathrm{w}$ Polsce pokrywane są $\mathrm{w} 78$ proc. surowcem importowanym, a ropy naftowej aż w 96 proc., przy czym nośniki te są głównie sprowadzane $\mathrm{z}$ kierunku wschodniego ${ }^{18}$. W $2019 \mathrm{r}$. w całej strukturze importu gaz ziemny z Rosji stanowił 60,2 proc., co oznaczało spadek o 6,6 proc. w porównaniu z rokiem poprzednim ${ }^{19}$, a ropa naftowa stanowiła 61,5 proc. (spadek o 6,5 proc.) ${ }^{20}$. Jakkolwiek pierwszorzędne znaczenie w zapewnieniu bezpieczeństwa energetycznego mają przede wszystkim

17 A quest for energy security in the $21^{\text {st }}$ century. Resources and constraints, Asia Pacific Energy Research Centre, Tokyo 2007, s. 6.

18 Zaktualizowany projekt..., s. 7.

19 Mniej gazu z Rosji, rośnie import LNG, PGNiG, Aktualności [online], 27 I 2020 [dostęp: 17 VI 2020], dostępny w internecie: <http://pgnig.pl/aktualnosci/-/news-list/id/ pgnig-mniej-gazu-z-rosji-rosnie-import-lng/newsGroupId/10184 $>$.

20 Bilans Płatniczy Rzeczypospolitej Polskiej za IV kwartał 2019 r., Narodowy Bank Polski, Warszawa 2020, s. 13-14. 
działania państwa związane z dywersyfikacją źródeł i kierunków dostaw, to jednak istotne znaczenie ma także aktywność o charakterze międzynarodowym. W przypadku Polski kluczowe znaczenie ma rozwój współpracy w ramach Unii Europejskiej oraz ze Stanami Zjednoczonymi w wymiarze transatlantyckim, ale i o charakterze regionalnym między państwami Inicjatywy Trójmorza. Jakkolwiek istnieje pewne zróżnicowanie pomiędzy tymi układami współpracy, chociażby co do zakładanych celów i stosowanych metod, to jednak w dużej mierze te wymiary aktywności międzynarodowej wzajemnie się uzupełniają. Podstawowym celem politycznym działań Polski w zakresie bezpieczeństwa energetycznego w odniesieniu do ropy naftowej i gazu ziemnego jest uniezależnienie się od wpływu Rosji, które jako państwo rewizjonistyczne może wykorzystywać nośniki energii do osiągania celów politycznych i przez to wpływać na układ sił w Europie i na świecie oraz pozycję Polski w stosunkach międzynarodowych. Potrzeba przyjmowania nowych rozwiązań w tym zakresie wynika, jak stwierdził premier Mateusz Morawiecki, z uznania, że bezpieczeństwo energetyczne jest obecnie tak samo ważne jak bezpieczeństwo militarne ${ }^{21}$.

Istotne znaczenie dla zapewnienia bezpieczeństwa dostaw gazu w szerszym wymiarze regionalnym ma koncepcja budowy w Polsce hubu gazowego dla Europy Środkowej i Wschodniej z uwzględnieniem państw bałtyckich. Zgodnie z przyjętą w 2017 r. przez rząd Strateğia na rzecz Odpowiedzialnego Rozwoju do roku 2020 (z perspektywa do 2030 r.), budowa hubu gazowego jest jednym z trzech projektów strategicznych, obok działań w zakresie rynku mocy i programu polskiej energetyki jądrowej, których celem jest poprawa bezpieczeństwa energetycznego Polski ${ }^{22}$. Budowa hubu gazowego, rozumianego jako centrum przesyłu i handlu gazem ${ }^{23}$, jest

21 Morawiecki: bezpieczeństwo energetyczne jest dla nas tak samo ważne jak militarne, Serwis informacyjny CIRE 24 [online], 29 I 2019 [dostęp: 17 VI 2020], dostęp w internecie: <https://www.cire.pl/item,175454,1,0,0,0,0,0,morawiecki-bezpieczenstwo-energetyczne-jest-dla-nas-tak-samo-wazne-jak-militarne-.html $>$.

22 Strategia na rzecz Odpowiedzialnego Rozwoju do roku 2020 (z perspektywa do 2030 r.), Rada Ministrów, Warszawa 2017, s. 328-329.

23 Jakkolwiek problem ten jest dyskutowany w literaturze przedmiotu, to jednak brakuje jednoznacznej definicji hubu gazowego $\mathrm{z}$ uwagi na różnorodne, a często sprzeczne koncepcje hubów. Można przyjąć definicję Międzynarodowej Agencji Energetycznej, dla której hub to platforma, gdzie tytuł (własność) cząsteczek gazu jest wymieniany między wieloma kupującymi i sprzedającymi 
najważniejszym elementem całej sieci infrastruktury gazowej, która obejmuje zarówno rurociągi, jak i terminal skroplonego gazu ziemnego (LNG) ${ }^{24}$. Hub służy jako centralny punkt cenowy dla gazu ziemnego w sieci, a jego konstrukcja wymaga spełnienia wielu istotnych warunków. Konieczna jest bowiem rozbudowa sieci rurociągów, posiadanie odpowiednich zdolności magazynowych w sytuacji dysponowania nadwyżkami gazowymi przy jednoczesnym zagwarantowaniu zróżnicowanych źródeł zaopatrzenia w gaz i posiadania grupy potencjalnych odbiorców.

Budowa przez Polskę hubu gazowego jako elementu uniezależnienia się od Rosji odbywa się w ramach strategii regionalnej, której wyrazem jest Inicjatywa Trójmorza. Od momentu zakończenia zimnej wojny istotnym graczem w obszarze Europy Środkowej i Wschodniej jest Polska, będąc jednym z inicjatorów w 1991 r. powstania Grupy Wyszehradzkiej, skupiającej cztery państwa: Polskę, Węgry, Czechy i Słowację. Aktywność Grupy, ograniczona do działań dyplomatycznych, przeżywała wzloty i upadki, ale to na ogół Polska, w odróżnieniu od innych państw, przywiązywała do niej dużą wagę, m.in. jako do narzędzia pozwalającego na koordynowanie w latach 90. XX w. dążeń do akcesji do NATO i Unii Europejskiej, a później do uzgadniania wspólnych stanowisk w ramach tych dwóch organizacji. Trójmorze można już traktować jako inną jakość współpracy w całym regionie Europy Środkowej i Wschodniej, gdyż jest to ambitny projekt mający na celu intensyfikowanie powiązań gospodarczych i infrastrukturalnych wśród państw zlokalizowanych między trzema morzami, tj. Bałtyckim, Adriatyckim i Czarnym. Ambicją Polski, która obok Chorwacji była inicjatorem tej nowej formy kooperacji, ale także innych zaangażowanych

zarówno w transakcjach spot, jak i kontraktach futures. Generalnie huby dzielimy na fizyczne, czyli centralnie zlokalizowane i wystarczająco połączone punkty geograficzne w sieci, w których ustalana jest cena gazu ziemnego dostarczanego w tych konkretnych miejscach, i wirtualne, czyli wirtualne punkty handlowe powiązane na obszarze rynku z systemem wejścia-wyjścia, z których użytkownicy mogą transportować gaz do punktów wyjścia (S. Xunpenga, H. M.P. Variam, Key elements for functioning gas hubs: A case study of East Asia, „Natural Gas Industry B” 2018, vol. 5, issue 2, s. 168-169).

24 QBA: What is a gas trading hub, and how are they established?, Reuters [online], 29 XII 2017 [dostęp: 15 V 2020], dostępny w internecie: <https://www.reuters. com/article/us-china-gas-exchange-q-a/qa-what-is-a-gas-trading-hub-and-howare-they-established-idUSKBN1ENoI1>. 
państw ${ }^{25}$, jest rozwój transgranicznych i makroregionalnych stosunków gospodarczych i infrastrukturalnych o znaczeniu strategicznym pomiędzy poszczególnymi państwami Trójmorza, lecz w ramach Unii Europejskiej. Zakłada się bowiem, że Trójmorze nie może stanowić alternatywy dla Unii Europejskiej ${ }^{26}$. Zgodnie z deklaracją prezydenta Andrzeja Dudy podczas Forum GLOBSEC 2017 w Bratysławie celem dwóch form współpracy regionalnej, tj. Bukareszteńskiej Dziewiątki w ramach NATo oraz Inicjatywy Trójmorza w ramach Unii Europejskiej, jest dążenie ostatecznie do budowy światowego pokoju, zaufania politycznego i ekonomicznej stabilności ${ }^{27}$. Polska nie zamierza tworzyć alternatywnych rozwiązań instytucjonalnych, ale poprzez wspólnotę regionalną chce się przyczynić do współtworzenia wspólnoty euroatlantyckiej. Współpraca w ramach Inicjatywy Trójmorza ma wobec tego charakter pragmatyczny. Jak podkreślono podczas pierwszego formalnego szczytu Trójmorza, który odbył się 25 sierpnia 2016 r.

25 W Inicjatywie Trójmorza uczestniczy 12 państw: Austria, Bułgaria, Chorwacja, Czechy, Estonia, Litwa, Łotwa, Polska, Rumunia, Słowacja, Słowenia i Węgry.

26 Mimo deklaracji można oczywiście zadać pytanie o geopolityczny wymiar Inicjatywy Trójmorza przede wszystkim w kontekście ewentualnej budowy alternatywnego układu wobec aktywności Niemiec w Unii Europejskiej i w relacjach z Rosją. Niektóre wypowiedzi polityków Prawa i Sprawiedliwości mogłyby to w jakiejś mierze sugerować. Np. Jarosław Kaczyński, podkreślając gospodarczy wymiar przedsięwzięcia, zwrócił także uwagę na znaczenie polityczne: „Chodzi o to, żeby tu, w środku Europy, powstał system powiązań gospodarczych, infrastrukturalnych i żeby powstał także pewien podmiot polityczny, który będzie równoważył układ w Europie i będzie prowadził do tego, że ci, którzy w tym układzie będą, będą silniejsi" (Prezes Pis: Międzymorze ma równoważyć układ w Europie, gospodarkamorska.pl [online], 14 XI 2017 [dostęp: 20 VI 2020], dostępny w internecie: <https://www.gospodarkamorska.pl/Administracja,Prawo/prezes-pis:-miedzymorze-ma-rownowazyc-uklad-weuropie.html >. Przy ocenie Trójmorza można postawić tezę, że jest to przede wszystkim projekt gospodarczy i infrastrukturalny, którego geopolityczne znaczenie polega na wzmocnieniu zaangażowanych państw w ramach Unii Europejskiej i w relacjach wobec Rosji, a nie na tworzeniu alternatywy wobec Unii. Więcej na temat geopolitycznego wymiaru Trójmorza patrz m.in. P. E. Thomann, The Three Seas Initiative, a new project at the heart of European and global geopolitical rivalries, "Rocznik Instytutu Europy Środkowo-Wschodniej" 2019, t. 17.

27 A. Duda, Bierzemy współodpowiedzialność za poziom światowego i europejskiego bezpieczeństwa, Prezydent.pl [online], 26 V 2017 [dostęp: 19 VI 2020], dostępny w internecie: <https://www.prezydent.pl/aktualnosci/wypowiedzi-prezydenta-rp/ wystapienia/art,222,bierzemy-wspolodpowiedzialnosc-za-poziom-swiatowego-ieuropejskiego-bezpieczenstwa.html>. 
w Dubrowniku, dzięki poszerzeniu współpracy w dziedzinie energii, transportu, komunikacji cyfrowej oraz poszczególnych sektorów gospodarczych Europa Środkowa i Wschodnia stanie się bardziej bezpieczna i konkurencyjna, przyczyniając się tym samym do wzmocnienia Unii Europejskiej jako całości ${ }^{28}$. Sektor energii stał się jednym z głównych obszarów strategicznej współpracy między państwami, co oczywiście oznacza, że jednym z podstawowych celów Inicjatywy Trójmorza jest zapewnienie bezpieczeństwa energetycznego poprzez dążenie do znacznego uniezależnienia się od Rosji. W taką strategię wpisują się projekty energetyczne realizowane przez Polskę, ale także sprzeciw wobec budowy przez Rosję i Niemcy gazociągu Nord Stream II na dnie Bałtyku.

Podstawowym celem strategicznym Polski w zakresie bezpieczeństwa rynku gazu ziemnego jest całkowite uniezależnienie się od Rosji przy jednoczesnym zagwarantowaniu dywersyfikacji źródeł i kierunków dostaw gazu. Zgodnie z Rozporządzeniem Rady Ministrów z dnia 24 kwietnia 2017 r. w sprawie minimalnego poziomu dywersyfikacji dostaw gazu ziemnego z zagranicy maksymalny udział gazu ziemnego importowanego z jednego źródła w danym roku kalendarzowym nie może być wyższy niż 70 proc. w latach 2017-2022 oraz 33 proc. w latach 2023-2026 ${ }^{29}$. Co więcej, w listopadzie 2019 r. Polskie Górnictwo Naftowe i Gazownictwo SA przekazało Gazpromowi oświadczenie woli, że 31 grudnia 2022 r. nastąpi zakończenie kontraktu na kupno gazu ziemnego z Rosji ${ }^{30}$. Generalnie kontrakt ten był uważany za niekorzystny z powodów politycznych, gdyż zbytnio uzależniał Polskę od gazu z Rosji w sytuacji neoimperialnej polityki prowadzonej przez to państwo i wykorzystywania nośników energii do osiągania celów politycznych. Ale także

28 Wspólna deklaracja $w$ sprawie Inicjatywy Trójmorza, Prezydent.pl [online], 25 VIII 2016 [dostęp: 19 VI 2020], dostępny w internecie: <https://www.prezydent.pl/ aktualnosci/wizyty-zagraniczne/art,105,wspolna-deklaracja-w-sprawie-inicjatywytrojmorza.html>.

29 Artykuł 3.1 Rozporządzenia Rady Ministrów z dnia 24 kwietnia 2017 r. w sprawie minimalnego poziomu dywersyfikacji dostaw gazu ziemnego z zagranicy, Dz. U. z 2017 poz. 902 z dnia 9 maja 2017 r.

30 Oświadczenie woli zakończenia Kontraktu Jamalskiego z dniem 31 grudnia 2022 roku, PGNiG, Aktualności [online], 15 XI 2019 [dostęp: 17 VI 2020], dostępny w internecie: <http://pgnig.pl/aktualnosci/-/news-list/id/oswiadczenie-woli-zakonczeniakontraktu-jamalskiego-z-dniem-31-grudnia-2022-roku/newsGroupId/10184? changeYear $=2019$ \& currentPage $=3>$. 
z punktu widzenia ekonomicznego kontrakt ten nie był uważany za zadowalający, czego wyrazem było postępowanie toczące się przed Trybunałem Arbitrażowym w Sztokholmie ${ }^{31}$. Zgodnie z wyrokiem wydanym w marcu 2020 r. Trybunał uznał cenę gazu w kontrakcie jamalskim za nierynkową i zawyżoną, gdyż nie była powiązana z poziomem cen na rynku europejskim $^{32}$. Wyrok ten zakończył aż pięcioletni spór o cenę gazu kupowanego w Rosji na podstawie kontraktu, który w Polsce budził dosyć spore kontrowersje $^{33}$. Odejście od kontraktu z Rosją ${ }^{34}$ wymaga podjęcia działań mających na celu zaspokojenie potrzeb Polski w zakresie zaopatrzenia w gaz ziemny, gdyż jak się oblicza, popyt w tym zakresie będzie rosnąć. Szacuje się, że w 2023 r. będzie on na poziomie od 20,1 do 23,6 $\mathrm{mld} \mathrm{m}^{3}$ gazu rocznie w porównaniu z 18 mld w 2019 r. Strategiia Polski sprowadza się do stworzenia hubu gazowego, czyli regionalnego centrum przesyłu i handlu gazem. Wykracza

31 Na temat sporu między Gazpromem a PGNiG patrz V. Yermakov, K. Sobczak, Russia-Poland gas relationship: risks and uncertainties of the ever after, The Oxford Institute for Energy Studies, 2020 (Energy Insight, 70), s. 11-14.

32 Nowy sposób określania ceny gazu dotyczy okresu od 1 listopada 2014 r., co jak szacuje PGNiG, oznacza, że Gazprom będzie zobowiązany zwrócić ok. 1,5 mld dol. (Zwycięstwo PGNiG: Trybunał Arbitrażowy w Sztokholmie orzekł niższa cenę gazu od Gazpromu dla PGNiG, PGNiG, Aktualności [online], 30 III 2020 [dostęp: 17 VI 2020], dostępny w internecie: <http://pgnig.pl/aktualnosci/-/news-list/id/zwyciestwo-pgnig-trybunalarbitrazowy-w-sztokholmie-orzekl-nizsza-cene-gazu-od-gazpromu-dla-pgnig/newsGroupId $/ 10184$ ?changeYear $=2020$ \&currentPage $=5>$. Jakkolwiek Gazprom odwołuje się od decyzji Trybunału Arbitrażowego, to 30 czerwca 2020 r. zwrócił PGNiG 1,5 mld dol. (PGNiG otrzymał 1,5 mld dolarów od Gazpromu, wGospodarce.pl [online], 30 VI 2020 [dostęp: 1 VII 2020], dostępny w internecie: <https://wgospodarce.pl/ informacje/81741-pgnig-otrzymal-15-mld-dolarow-od-gazpromu $\rangle$.

33 Podpisanie kontraktu, negocjowanego przez rząd PO-PSL Donalda Tuska, zostało w 2010 r. wstrzymane przez Komisję Europejską z uwagi na sprzeczność jego zapisów z prawem europejskim. Pierwotnie miał on obwiązywać aż do 2037 r., ale po interwencji Komisji kontrakt ma wygasnąć pod koniec 2022 r. Wadami kontraktu są: konieczność zapłaty nawet za nieodebrany gaz poniżej poziomu 8,7 mld $\mathrm{m}^{3}$ gazu rocznie, brak możliwości reeksportu surowca przez Polskę i powiązanie, aż do wyroku Trybunału Arbitrażowego, ceny gazu z ceną ropy naftowej, co m.in. powodowało, że cena gazu dla Polski była wyższa niż dla Niemiec (Koniec kontraktu jamalskiego. Polski sektor gazu wkracza w nowa erę, Warsaw Institute [online], 6 XII 2019 [dostęp: 24 VI 2020], dostępny w internecie: <https://warsawinstitute. org/pl/koniec-kontraktu-jamalskiego-polski-sektor-gazu-wkracza-w-nowa-ere/ $>$.

34 Możliwe jest kontynuowanie tego kontraktu w przyszłości, ale na warunkach korzystnych dla obu stron bez podlegania presji ze strony Rosji. 
więc poza kwestię zaspokojenia jedynie potrzeb wewnętrznych, ale ma także na celu wzmocnienie pozycji Polski na rynku europejskim, przede wszystkim Europy Środkowej i Wschodniej, czyli w ramach Inicjatywy Trójmorza. Obejmuje ona swoim zakresem wiele działań, $w$ tym przede wszystkim oddanie do użytku w 2016 r. Terminalu LNG im. Prezydenta Lecha Kaczyńskiego w Świnoujściu, odbierającego gaz skroplony przede wszystkim ze Stanów Zjednoczonych i Kuwejtu, oraz budowę do października 2022 r. Gazociągu Bałtyckiego (Baltic Pipe), dzięki któremu zostanie stworzony korytarz dostaw gazu ze złóż norweskich ${ }^{35}$ do Polski poprzez Danię. Planuje się także wybudowanie do $2025 \mathrm{r}$. pierwszego etapu pływającego terminalu regazyfikacyjnego gazu ziemnego w Zatoce Gdańskiej i dodatkowych odcinków gazociągów ${ }^{36}$. Te plany i działania, określane mianem budowy Bramy Północnej, są najważniejszym projektem rządu w zakresie zapewnienia bezpieczeństwa gazowego Polski ${ }^{37}$. Mają one stanowić wyraźną konkurencją dla gazociągu Nord Stream II i mieszczą się w ramach współpracy między państwami Inicjatywy Trójmorza oraz Grupy Wyszehradzkiej. Świadczą o tym inne elementy strategii Polski, takie jak budowa lub rozbudowa połączeń z państwami sąsiadującymi, tj. ze Słowacją i Litwą, a w przyszłości z Czechami i Ukrainą, oraz rozbudowa sieci krajowej, tj. od Świnoujścia do połączeń z Czechami, Słowacją, Ukrainą i do połączenia z Litwą, oraz infrastruktury magazynowej. Działania te mają na celu stworzenie korytarza gazowego Północ-Południe, którego koncepcja została uzgodniona na zwołanym w Budapeszcie 24 lutego 2010 r. z inicjatywy Grupy Wyszehradzkiej szczycie Grupy V4 ${ }^{38}$ w sprawie

35 W maju 2020 r. Polskie Górnictwo Naftowe i Gazownictwo już posiadało aż 31 koncesji na wydobycia zasobów ropy naftowej i gazu ziemnego na Norweskim Szelfie Kontynentalnym (PGNiG ma już 31 koncesji na Norweskim Szelfie Kontynentalnym, PGNiG, Aktualności [online], 5 V 2020 [dostęp: 17 VI 2020], dostępny w internecie: <http://pgnig.pl/aktualnosci/-/news-list/id/pgnig-ma-juz-31-koncesji-na-norweskimszelfie-kontynentalnym/newsGroupId/10184 $>$.

36 Zaktualizowany projekt Polityki energetycznej..., s. 29-30.

37 M. Kurtyka (wiceminister energii): dzięki dostawom $z$ Norwegii gaz dla konsumentów będzie tańszy. Brama Północna to nasz najważniejszy projekt, Biznes Newseria [online], 21 XI 2016 [dostęp: 26 VI 2020], dostępny w internecie: <https://biznes. newseria.pl/news/m-kurtyka-wiceminister,p18651138>.

38 Oprócz państw Grupy Wyszehradzkiej, tj. Czech, Polski, Słowacji i Węgier, w posiedzeniu wzięli udział wysokiej rangi przedstawiciele Austrii, Bośni i Hercegowiny, Bułgarii, Chorwacji, Serbii, Słowenii i Rumunii. 
bezpieczeństwa energetycznego ${ }^{39}$. W przyjętej deklaracji wyrażono poparcie dla działań mających na celu współpracę na rzecz dalszej integracji sieci gazowych oraz dywersyfikacji tras i źródeł zaopatrzenia, a w tym kontekście wymieniono m.in. projekt budowy korytarza gazowego Północ-Południe między wówczas planowanymi terminalami gazu skroplonego LNG w Chorwacji i w Polsce ${ }^{40}$. Projekt ten zyskał poparcie Komisji Europejskiej i został wpisany na listę priorytetowych projektów infrastrukturalnych mających podlegać realizacji do 2020 r. Został on potraktowany jako część strategii Unii Europejskiej, której celem jest zapewnienie zróżnicowanych dostaw gazu do w pełni połączonej i elastycznej europejskiej sieci gazowej obejmującej również takie projekty jak korytarz południowy, realizację planu połączeń międzysystemowych na rynku energii państw bałtyckich w sektorze gazu oraz korytarz Północ-Południe w Europie Zachodniej ${ }^{41}$.

\section{Strategia bezpieczeństwa energetycznego Polski w wymiarze europejskim i transatlantyckim}

Strategia Polski, realizowana w dużej mierze w ramach Inicjatywy Trójmorza, wpisuje się we współpracę w ramach Unii Europejskiej i w wymiarze transatlantyckim $\mathrm{w}$ zakresie bezpieczeństwa energetycznego. $\mathrm{W}$ tym kontekście pojawiają się także kwestie sporne, które mają zarówno wpływ na politykę Polski, jak i na stosunki w ramach Unii Europejskiej i Sojuszu Północnoatlantyckiego. Podstawowym zagadnieniem wywołującym kontrowersje jest kwestia budowy rurociągu Nord Stream II, wokół którego ogniskuje się nie tylko dyskusja na temat bezpieczeństwa energetycznego Europy, ale przede wszystkim strategiczna debata o relacjach z Rosją i wpływie tego

39 Informacja na temat Grupy Wyszehradzkiej, Kancelaria Senatu, Biuro Spraw Międzynarodowych i Unii Europejskiej, Warszawa 2012, s. 11.

40 Deklaracja szczytu budapeszteńskiego Grupy Wyszehradzkiej Plus w sprawie bezpieczeństwa energetycznego, Budapeszt, Senat RP, Warszawa [online], 24 II 2010 [dostęp: 26 VI 2020], dostępny w internecie: <http://ww2.senat.pl/k7/partnerstwo/ budapesztpl.pdf>.

41 European Commission, Communication from the Commission to the European Parliament, the Council, the European Economic and Social Committee and the Committee of the Regions. Energy infrastructure priorities for 2020 and beyond A Blueprint for an integrated European energy network, Brussels, 17 XI 2010, $\operatorname{com}(2010) 677$ final, s. 31-35. 
państwa na kształtowanie architektury bezpieczeństwa na całym obszarze euroatlantyckim. W Polsce już decyzja o budowie gazociągu Nord Stream budziła sprzeciw, gdyż wskazywano na nieekonomiczność całego przedsięwzięcia oraz zagrożenia dla środowiska ${ }^{42}$. Podnoszono bardzo istotny argument polityczny, że budowa rurociągu po dnie Morza Bałtyckiego ma związek z polityką zagraniczną Rosji, która próbuje ominąć terytorium Polski, ale również Ukrainy i Białorusi, dostarczając gaz do Europy Zachodniej. W 2006 r. ówczesny minister obrony narodowej w rządzie Pis Radosław Sikorski podczas szczytu amerykańsko-europejskiego w Brukseli porównał gazociąg bałtycki wręcz do paktu Ribbentrop-Mołotow, co wywołało bardzo ostre reakcje polityków niemieckich ${ }^{43}$. Jednak próby przeciwdziałania realizacji projektu nie powiodły się z uwagi na determinację Rosji i możliwości Gazpromu oferowania zachodnim firmom zachęt w postaci dostępu do rosyjskiego rynku energetycznego oraz Niemiec, w których interesie było poszukiwanie alternatywnych źródeł energii dla pomysłu stopniowego wygaszania elektrowni jądrowych. Stanowisko Niemiec nie zmieniło się nawet po zmianie rządu, kiedy socjaldemokratycznego kanclerza Gerharda Schrödera, który szybko został przewodniczącym Rady Dyrektorów rosyjsko-niemieckiego konsorcjum budującego gazociąg ${ }^{44}$, zastąpiła Angela Merkel reprezentująca chadecję. W takiej sytuacji premier Donald Tusk, uznając, że nie jest w stanie zablokować inwestycji, stwierdził jedynie w 2007 i 2008 r., że Polska nie akceptuje projektu i nie weźmie w nim udziału ${ }^{45}$. Pojawiały się jednak głosy przeciwne takiemu podejściu. Na przykład były

42 R. Rosicki, G. Rosicki, Znaczenie gazociagu Nord Stream dla Polski, „Przegląd Bezpieczeństwa Wewnętrznego" 2012, t. 4, nr 6, s. 141-146.

43 Niemcy wściekłe na Sikorskiego, Gazeta.pl [online], 4 V 2006 [dostęp: 15 IV 2020], dostępny w internecie: 〈https://wiadomosci.gazeta.pl/wiadomosci/1,114873,3321425.html〉.

44 Kontrakt na budowę rurociągu Nord Stream został podpisany w dosyć niecodziennych okolicznościach, gdyż stało się to w obecności kanclerza Niemiec Gerharda Schrödera i prezydenta Rosji Władimira Putina 8 września 2008 r., czyli na kilka dni przed wyborami w Niemczech. Schröder przegrał te wybory, ale jeszcze zdołał udzielić wielomiliardowych gwarancji na realizację projektu, a kilka tygodni później został przewodniczącym Rady Nadzorczej firmy szwajcarskiej odpowiedzialnej za budowę Nord Stream (S. Raabe, The dispute over the Baltic Gas Pipeline. A threat or a necessary supply project?”, Konrad-Adenauer-Stiftung, „Auslandsinformationen” 2009, nr 2).

45 M. Lasoń, Polska wobec wyzwań bezpieczeństwa energetycznego, [w:] Międzynarodowe bezpieczeństwo enerǵetyczne w XXI wieku, red. E. Cziomer, Krakowska Szkoła Wyższa im. Andrzeja Frycza Modrzewskiego, Kraków 2008, s. 257-258. 
prezydent Aleksander Kwaśniewski opowiadał się za depolityzacją kwestii gazociągu i uważał, że Polska powinna włączyć się w projekt, który może się stać częścią wspólnej europejskiej polityki energetycznej ${ }^{46}$. Było to jednak stanowisko niezbyt powszechne, gdyż Kwaśniewski został szybko dosyć mocno skrytykowany zarówno przez polityków Platformy Obywatelskiej, jak i Prawa i Sprawiedliwości.

Oddanie do użytku w 2011 i 2012 r. rurociągu Nord Stream nie rozwiało wszystkich kontrowersji. Zostały one jeszcze bardziej wzmocnione po agresji Rosji na Ukrainę i aneksji Krymu w 2014 r. Mimo tych wydarzeń, będących zagrożeniem dla bezpieczeństwa europejskiego, we wrześniu $2015 \mathrm{r}$. zostało podpisane porozumienie między Gazpromem a pięcioma europejskimi firmami energetycznymi w sprawie budowy gazociągu Nord Stream $\mathrm{II}^{47}$. Realizacja tego projektu doprowadziła do jeszcze ostrzejszej polaryzacji stanowisk pomiędzy Niemcami a Polską. Kanclerz Angela Merkel bardzo wyraźnie podkreśla gospodarczy wymiar projektu, uważając, że jego realizacja nie doprowadzi do zwiększenia zależności Niemiec od gazu z Rosji, gdyż "cząsteczka rosyjskiego gazu pozostaje cząsteczką rosyjskiego gazu, bez względu na to czy dostarczana jest przez Ukrainę, czy przez Bałtyk" ${ }^{\text {"48 }}$. Co więcej, akcentuje, że rosyjski gaz ziemny był już importowany w okresie zimnej wojny ${ }^{49}$.

46 Kwaśniewski: Nord Stream może być korzystny dla Polski, „Rzeczpospolita” [online], 17 VII 2008 [dostęp: 26 VI 2020], dostępny w internecie: <https://www.rp.pl/artykul/163681-Kwasniewski--Nord-Stream-moze-byc-korzystny-dla-Polski.html >; S. Bouzarovski, M. Konieczny, Landscapes of paradox: public discourses and policies in Poland's relationship with the Nord Stream Pipeline, „Geopolitics” 2010, vol. 15, issue 1, s. 11.

47 Udziałowcami projektu są następujące firmy: Gazprom (50 proc.), E.on (10 proc.), OMV (10 proc.), Shell (10 proc.), Wintershall (10 proc.), ENGIE (10 proc.) (The Nord Stream 2 pipeline project, European Parliamentary Research Service [online], IV 2016 [dostęp: 30 VI 2020], dostępny w internecie: <https://euagenda.eu/upload/ publications/untitled-63175-ea.pdf $>$ ).

48 Speech by Federal Chancellor Dr Angela Merkel on 16 February 2019 at the 55th Munich Security Conference, [online] 16 II 2019 [dostęp: 12 VI 2020], dostępny w internecie: $<$ https://www.bundesregierung.de/breg-en/news/speech-by-federal-chancellor-dr-angela-merkel-on-16-february-2019-at-the-55th-munich-security-conference-1582318>.

49 Jednak już w okresie zimnej wojny kwestia dostaw gazu ze Związku Sowieckiego do Europy Zachodniej budziła kontrowersje. Konstrukcja w latach 8o. gazociągu jamalskiego doprowadziła do bardzo ostrego sporu pomiędzy Stanami Zjednoczonymi, które początkowo wprowadziły eksterytorialne sankcje na jego budowę, a państwami Europy Zachodniej (A. Podraza, Stosunki polityczne i gospodarcze Wspólnoty Europejskiej z państwami Europy Środkowej i Wschodniej, Redakcja Wydawnictw Katolickiego Uniwersytetu Lubelskiego, Lublin 1996, s. 111-122). 
Biznesowe podejście Niemiec stoi $\mathrm{w}$ całkowitej sprzeczności z krytycznym geopolitycznym stanowiskiem Polski, która próbuje przeciwdziałać budowie Nord Stream II, wykorzystując współpracę transatlantycką oraz europejską. Polska jest wspierana w swoim sprzeciwie przez Stany Zjednoczone - zarówno przez administrację prezydenta Baracka Obamy, jak i Donalda Trumpa ${ }^{50}$. Stanowisko amerykańskie jest w dużej mierze rezultatem aneksji Krymu, gdyż Stany Zjednoczone traktują Nord Stream II jako narzędzie, którego używa Rosja do wspierania ciągłej agresji na Ukrainę, która przez to nie może ściślej zintegrować się z Europą i Stanami Zjednoczonymi ${ }^{51}$. Prezydent Donald Trump niejednokrotnie krytykował w tym kontekście Niemcy, które, jak podkreślał, płacą Rosji miliardy za energię płynącą z gazociągu Nord Stream II, ale jednocześnie są chronione militarnie przez Stany Zjednoczone ${ }^{52}$.Zagadnienie to pojawia się w kontekście braku należytych nakładów finansowych Niemiec na obronność, którym daleko do 2 proc. PKB, co wynika z uzgodnień w ramach NATO oraz decyzji o wycofaniu prawie 10 tys. amerykańskich żołnierzy z Niemiec ${ }^{53}$. Sankcje wobec budowy gazociągu Nord Stream II są również wspierane przez Kongres USA. W lipcu 2017 r. najpierw Izba Reprezentantów, a później Senat przyjęły ustawę o sankcjach wobec Rosji. Ustawa dotyczy również sektora energetycznego, gdyż sankcje są wymierzone wobec firm amerykańskich i zagranicznych, które inwestują w projekty naftowe i gazowe w Rosji, w tym

50 J. Techau, The foreign policy of Germany: economic giant, foreign policy dwarf?, [w:] Europe and America. The end of the transatlantic relationship?, ed. F. Bindi, Brookings Institution Press, Washington DC 2019, s. 86.

51 Fact Sheet on U.S. Opposition to Nord Stream 2, Bureau of Energy Resources, U.S. Department of State [online], 27 XII 2019 [dostęp: 15 V 2020], dostępny w internecie: 〈https://pl.usembassy.gov/nord_stream2/>.

52 „Przepraszam, ale jak to działa?” Trump krytykuje Niemcy za kupowanie energii od Rosji, TVN24 [online], 21 VI 2020 [dostęp: 22 VI 2020], dostępny w internecie: <https://tvn24.pl/swiat/usa-donald-trump-o-nord-stream-2-krytykuje-niemcyza-kupowanie-energii-od-rosji-4616318 >. Tak samo o Niemczech wypowiada się premier Mateusz Morawiecki, który podczas dyskusji w Hamburgu dodał jeszcze, że Rosja wydaje środki uzyskane za gaz na zbrojenia (Premier Morawiecki w Hamburgu o Nord Stream 2 i armii UE, Deutsche Welle [online], 17 XI 2018 [dostęp: 15 IV 2020], dostępny w internecie: <https://www.dw.com/pl/premier-morawieckiw-hamburgu-o-nord-stream-2-i-armii-ue/a-46340361 >.

53 J.Bielecki, Prezydent USA wycofuje część wojska $z$ Niemiec $i$ gra Europa, „Rzeczpospolita”, 1 VII 2020. 
w Nord Stream II $^{54}$. W uzasadnieniu podkreślono, że Rosja jest państwem, które narusza integralność terytorialną i suwerenność Ukrainy. W reakcji działania amerykańskie zostały bardzo ostro skrytykowane przez ministrów spraw zagranicznych Niemiec i Austrii, którzy uznali, że zagrażają one bezpieczeństwu energetycznemu Europy ${ }^{55}$, a Stany Zjednoczone faworyzują przez to amerykańskie koncerny energetyczne. Stany Zjednoczone jednak konsekwentnie dążą do wstrzymania budowy gazociągu, czego wyrazem była Ustawa chroniaca bezpieczeństwo energetyczne Europy, podpisana przez prezydenta Donalda Trumpa 20 grudnia 2019 r., która wprowadziła sankcje związane z udostępnianiem statków do budowy rosyjskich rurociągów eksportujący energię ${ }^{56}$. Cel ten został osiągnięty, gdyż z uwagi na wycofanie się kluczowego podwykonawcy projektu, tj. szwajcarskiej spółki Allseas, prace nad gazociągiem przerwano, przynajmniej czasowo ${ }^{57}$.

Polska stara się również wykorzystać współpracę w ramach Unii Europejskiej do przeciwdziałania negatywnym skutkom budowy Nord Stream II dla bezpieczeństwa energetycznego. Determinacja Polski w zakresie nowelizacji unijnej dyrektywy gazowej była na tyle duża, że rosyjski dziennik „Kommiersant” przekonywał, że tylko Polska lobbuje za rewizją tego dokumentu, co nie odpowiadało rzeczywistości ${ }^{58}$. Dyrektywa, przyjęta przez Parlament Europejski i Radę 17 kwietnia 2019 r., dotyczy wspólnych zasad rynku wewnętrznego gazu ziemnego ${ }^{59}$. Objęła ona swoim zakresem

54 A. Dąbrowski, A. Legucka, Sankcje USA wobec Rosji, Polski Instytut Spraw Międzynarodowych, 31 VII 2017 (Biuletyn PISM, 73).

55 Autorzy ustawy uważali natomiast, że projekt Gazpromu ma szkodliwy wpływ na bezpieczeństwo energetyczne UE (R. Korteweg, Nord Stream 2 will divide the EU, but new US sanctions will do more harm, Euractiv [online], 26 VII 2017 [dostęp: 16 VIII 2017], dostępny w internecie: <https://www.euractiv.com/section/energy/opinion/ nord-stream-2-will-divide-the-eu-but-new-us-sanctions-will-do-more-harm/ $>$.

56 Fact Sheet on U. S. Opposition...

57 B. Bieliszczuk, Starania Gazpromu o ukończenie Nord Stream 2 i utrzymanie nad nim kontroli, Polski Instytut Spraw Międzynarodowych, 14 V 2020 (Biuletyn PISM, 105).

58 W. Jakóbik, Rosja nadal próbuje izolować Polskę w grze o Nord Stream 2, Biznes Alert [online], 1 II 2018 [dostęp: 14 III 2019], dostępny w internecie: <https://biznesalert. $\mathrm{pl} /$ polska-rosja-nord-stream-2-dyrektywa-gazowa/>.

59 Dyrektywa Parlamentu Europejskiego i Rady (UE) 2019/692 z dnia 17 kwietnia 2019 r. zmieniająca dyrektywę 2009/73/WE dotyczącą wspólnych zasad rynku wewnętrznego gazu ziemnego, Dziennik Urzędowy Unii Europejskiej, L 117/1, 3 V 2019. 
gazociągi łączące Unię Europejską z państwami trzecimi, co spowodowało obawy ze strony Gazpromu, że utraci kontrolę nad gazociągiem Nord Stream II po oddaniu go do użytku ${ }^{60}$. Niepokój Gazpromu związany jest z tymi przepisami dyrektywy, zgodnie z którymi operatorem gazociągu musi być podmiot niezależny od sprzedawcy gazu, należy umożliwić dostęp do niego stron trzecich, jak też stosować przejrzyste taryfy. Jednak sama dyrektywa powstała w wyniku kompromisów między państwami członkowskimi, które pozwalają na stosowanie pewnych odstępstw od jej zapisów, toteż jej ostateczna wersja nie wzbudziła zbytniego zachwytu ze strony rządzącej partii Prawa i Sprawiedliwości, której deputowani do Parlamentu Europejskiego wstrzymali się od głosu w ostatecznym głosowaniu ${ }^{61}$. Dlatego premier Morawiecki podkreślał, że „będziemy bardzo mocno patrzeć na ręce Komisji Europejskiej, jak jest wdrażana ta dyrektywa gazowa" ${ }^{162}$.

\section{Zakończenie}

Analiza działań Polski w zakresie zapewnienia bezpieczeństwa energetycznego, jeżeli chodzi o gaz ziemny, może prowadzić do wniosku o ich skuteczności, jakkolwiek długoterminowe skutki, chociażby $\mathrm{w}$ odniesieniu do ewentualnych zmian cen surowca, są trudne do przewidzenia. Niemniej jednak Polska osiąǵnęła zakładany cel uniezależnienia się od Rosji jako głównego dostawcy tego istotnego nośnika energii, przez co zlikwidowała możliwości podlegania szantażom ze strony tego państwa. Istotnym elementem aktywności Polski jest ograniczanie zależności całej Europy Środkowej i Wschodniej od Rosji, czego wyrazem jest projekt stworzenia w Polsce hubu gazowego dla całego regionu. Projekt ten jest realizowany w ramach Inicjatywy Trójmorza i zyskał m.in. poparcie Stanów Zjednoczonych. Wyrazem tego poparcia był udział Donalda Trumpa w spotkaniu na szczycie Inicjatywy Trójmorza, które odbyło się

60 B. Bieliszczuk, Starania Gazpromu o ukończenie Nord Stream 2...

61 Nowe przepisy dotyczące Nord Stream 2 weszły $w \dot{z} y c i e$, TVN24 [online], 23 V 2020 [dostęp: 22 VI 2020], dostępny w internecie: <https://tvn24.pl/biznes/ze-swiata/ dyrektywa-gazowa-dotyczaca-nord-stream-2-weszla-w-zycie-ra938138-4507490 >.

62 Morawiecki: Będziemy pilnować stosowania dyrektywy gazowej przez KE, Biznes Alert [online], 15 IV 2019 [dostęp: 14 III 2019], dostępny w internecie: <https://biznesalert.pl/morawiecki-ke-dyrektywa-gazowa/>. 
w lipcu 2017 r. w Warszawie. Prezydent USA wyraził satysfakcję z dostaw amerykańskiego gazu do terminalu LNG w Świnoujściu, co jego zdaniem pomoże państwom Inicjatywy osiąǵnąć bardzo potrzebną dywersyfikację energii ${ }^{63}$. W związku z tym Stany Zjednoczone angażują się w pomoc finansową dla projektów energetycznych realizowanych w ramach Partnerstwa Trójmorza poprzez agencję rządową International Development Finance Corporation (IDFC) oraz inicjatywę Partnerstwa na rzecz Transatlantyckiej Współpracy Energetycznej ${ }^{64}$. Mimo krytycznego stanowiska Polski wobec budowy gazociągu Nord Stream II Niemcy również zauważają dla siebie korzyści z funkcjonowania Inicjatywy Trójmorza. Po początkowo negatywnym podejściu do Inicjatywy, od szczytu w Bukareszcie we wrześniu $2018 \mathrm{r}$. Niemcy uczestniczą w pracach Trójmorza jako obserwator i są żywo zainteresowane rozwojem połączeń infrastrukturalnych na osi Północ-Południe ${ }^{65}$. Polityka Polski przynosi więc pożądane rezultaty w wymiarze międzynarodowym, służąc rozwojowi relacji z innymi partnerami, ale również wewnętrznym, zapewniając bezpieczeństwo energetyczne.

\section{Bibliografia}

Asia Pacific Energy Research Centre, A quest for energy security in the $21^{\text {st }}$ century. Resources and constraints, Tokyo 2007.

Bielecki J., Prezydent USA wycofuje część wojska $z$ Niemiec i gra Europa, „Rzeczpospolita", 1 VII 2020.

Bieliszczuk B., Starania Gazpromu o ukończenie Nord Stream 2 i utrzymanie nad nim kontroli, Polski Instytut Spraw Międzynarodowych, 14 V 2020 (Biuletyn PISM, 105).

Biuro Spraw Międzynarodowych i Unii Europejskiej, Informacja na temat Grupy Wyszehradzkiej, Kancelaria Senatu, Warszawa 2012.

63 Three Seas Initiative: Trump in Warsaw supports the project, Visegrad Post [online], 8 VII 2017 [dostęp: 15 V 2020], dostępny w internecie: <https://visegradpost.com/ en/2017/07/o8/three-seas-initiative-trump-in-warsaw-supports-the-project/ $>$.

64 P. Wilczek, Wspótpraca polsko-amerykańska w latach 2016-2020. Fakty i liczby, The Warsaw Institute Review [online], 15 VI 2020 [dostęp: 4 VII 2020], dostępny w internecie: 〈https://warsawinstitute.review/pl/aktualnosci/wspolpraca-polskoamerykanska-w-latach-2016-2020/>.

65 Ł. Janulewicz, T. Żornaczuk, Niemcy wobec Inicjatywy Trójmorza, Polski Instytut Spraw Międzynarodowych, 22 VIII 2019 (Biuletyn PISM, 120). 
Blackwill R., Harris J., War by other means. Geoeconomics and statecraft, Harvard University Press, Cambridge Mass. 2016.

Bouzarovski S., Konieczny M., Landscapes of paradox: public discourses and policies in Poland's relationship with the Nord Stream Pipeline, „Geopolitics” 2010, vol. 15, issue 1.

Dąbrowski A., Legucka A., Sankcje USA wobec Rosji, Polski Instytut Spraw Międzynarodowych, 31 VII 2017 (Biuletyn PISM, 73).

Deklaracja szczytu budapeszteńskiego Grupy Wyszehradzkiej Plus w sprawie bezpieczeństwa enerǵetycznego, Budapeszt, Senat RP, Warszawa, 24 II 2010 [dostęp: 26 VI 2020], dostępny w internecie: <http://ww2.senat.pl/k7/partnerstwo/budapesztpl.pdf $>$.

Duda A., Bierzemy współodpowiedzialność za poziom światowego i europejskiego bezpieczeństwa, 26 V 2017 [dostęp: 19 VI 2020], dostępny w internecie: <https:// www.prezydent.pl/aktualnosci/wypowiedzi-prezydenta-rp/wystapienia/art,222, bierzemy-wspolodpowiedzialnosc-za-poziom-swiatowego-i-europejskiegobezpieczenstwa.html>.

Dyrektywa Parlamentu Europejskiego i Rady (UE) 2019/692 z dnia 17 kwietnia 2019 r. zmieniająca dyrektywę 2009/73/WE dotycząca wspólnych zasad rynku wewnętrznego gazu ziemnego, Dziennik Urzędowy Unii Europejskiej, L 117/1, 3 V 2019.

European Commission, Communication from the Commission to the European Parliament, the Council, the European Economic and Social Committee and the Committee of the Regions. Energy infrastructure priorities for 2020 and beyond A blueprint for an integrated European energy network, Brussels, 17 XI 2010, $\operatorname{com}(2010) 677$ final.

European Parliamentary Research Service, The Nord Stream 2 pipeline project [online], IV 2016 [dostęp: 30 VI 2020], dostępny w internecie: <https://euagenda. eu/upload/publications/untitled-63175-ea.pdf $>$.

Fact Sheet on U.S. Opposition to Nord Stream 2, Bureau of Energy Resources, U. S. Department of State, 27 XII 2019 [dostęp: 15 V 2020], dostępny w internecie: 〈https://pl.usembassy.gov/nord_stream2/>.

Foreign Policy Concept of the Russian Federation (approved by President of the Russian Federation Vladimir Putin on November 30, 2016), The Ministry of Foreign Affairs of the Russian Federation [dostęp: 10 VI 2020], dostępny w internecie: <https://www.mid.ru/en/foreign_policy/official_documents/-/asset_publisher/ CptickB6BZ29/content/id/2542248>.

Götz E., Merlen C.-R., Russia and the question of world order, „European Politics and Society" 2019, vol. 20, issue 2.

Holsti K. J., The decline of international politics as an academic discipline: can it be saved?, „Global Affairs" 2019, vol. 5, issue 4-5.

Jakóbik W., Rosja nadal próbuje izolować Polskę w grze o Nord Stream 2, Biznes Alert [online], 1 II 2018 [dostęp: 14 III 2019], dostępny w internecie: <https://biznesalert.pl/polska-rosja-nord-stream-2-dyrektywa-gazowa/>.

Janulewicz Ł., Żornaczuk T., Niemcy wobec Inicjatywy Trójmorza, Polski Instytut Spraw Międzynarodowych, 22 VIII 2019 (Biuletyn PISM, 120). 
Kardaś S., Nowa strategia enerǵetyczna Rosji - optymistyczne plany $w$ niepewnych czasach, Warszawa, 15 IV 2020 (Ośrodek Studiów Wschodnich. Komentarze 325). Koniec kontraktu jamalskiego. Polski sektor gazu wkracza w nowa erę, „Warsaw Institute" [online], 6 XII 2019 [dostęp: 24 VI 2020], dostępny w internecie: <https://warsawinstitute.org/pl/koniec-kontraktu-jamalskiego-polski-sektorgazu-wkracza-w-nowa-ere/ $>$.

Korteweg R., Nord Stream 2 will divide the EU, but new US sanctions will do more harm, Euractiv [online], 26 VII 2017 [dostęp: 16 VIII 2017], dostępny w internecie: $<$ https://www.euractiv.com/section/energy/opinion/nord-stream-2-will-dividethe-eu-but-new-us-sanctions-will-do-more-harm/ $>$.

Kwaśniewski: Nord Stream może być korzystny dla Polski, „Rzeczpospolita” [online], 17 VII 2008 [dostęp: 26 VI 2020], dostępny w internecie: <https://www.rp.pl/artykul/163681-Kwasniewski--Nord-Stream-moze-byc-korzystny-dla-Polski.html >.

Lasoń M., Polska wobec wyzwań bezpieczeństwa energetycznego, [w:] Międzynarodowe bezpieczeństwo energetyczne w XXI wieku, red. E. Cziomer, Krakowska Szkoła Wyższa im. Andrzeja Frycza Modrzewskiego, Kraków 2008.

Lough J., Russia's energy diplomacy, Chatham House, London, V 2011 (Chatham House Briefing Paper).

Luttwak E. N., From geopolitics to geo-economics: logic of conflict, grammar of commerce, „The National Interest” 1990, issue 20.

M. Kurtyka (wiceminister energii): dzięki dostawom z Norwegii gaz dla konsumentów będzie tańszy. Brama Północna to nasz najważniejszy projekt, Biznes Newseria [online], 21 XI 2016 [dostęp: 26 VI 2020], dostępny w internecie: <https://biznes.newseria.pl/news/m-kurtyka-wiceminister,p18651138>.

Ministerstwo Gospodarki, Zaktualizowany projekt polityki energetycznej Polski do 2040 r., Warszawa 2019.

Ministry of Energy of the Russian Federation, Energy strategy of Russia for the period up to 2030. Approved by Decree $N^{\circ} 1715-r$ of the Government of the Russian Federation dated 13 November 2009, Moscow 2010.

Mniej gazu z Rosji, rośnie import LNG, PGNiG, Aktualności [online], 27 I 2020 [dostęp: 17 VI 2020], dostępny w internecie: <http://pgnig.pl/aktualnosci/-/news-list/id/ pgnig-mniej-gazu-z-rosji-rosnie-import-lng/newsGroupId/10184>.

Morawiecki: bezpieczeństwo enerǵetyczne jest dla nas tak samo ważne jak militarne, Serwis informacyjny CIRE 24 [online], 29 I 2019 [dostęp: 17 VI 2020], dostęp w internecie: 〈https://www.cire.pl/item,175454,1,0,0,0,0,0,morawiecki-bezpieczenstwo-energetyczne-jest-dla-nas-tak-samo-wazne-jak-militarne-.html >.

Morawiecki: Będziemy pilnować stosowania dyrektywy gazowej przez KE, Biznes Alert [online], 15 IV 2019 [dostęp: 14 III 2019], dostępny w internecie: https://biznesalert.pl/morawiecki-ke-dyrektywa-gazowa/>.

Narodowy Bank Polski, Bilans Płatniczy Rzeczypospolitej Polskiej za IV kwartał 2019 r., Warszawa 2020.

Niemcy wściekłe na Sikorskiego, Gazeta.pl [online], 4 V 2006 [dostęp: 15 IV 2020], dostępny w internecie: 〈https://wiadomosci.gazeta.pl/wiadomosci/1,114873,3321425.html〉. 
Nowe przepisy dotyczące Nord Stream 2 weszły $w \dot{z y c i e}$, TVN24 [online], $23 \mathrm{~V} 2020$ [dostęp: 22 VI 2020], dostępny w internecie: <https://tvn24.pl/biznes/ze-swiata/ dyrektywa-gazowa-dotyczaca-nord-stream-2-weszla-w-zycie-ra938138-4507490 >.

Oświadczenie woli zakończenia Kontraktu Jamalskiego z dniem 31 grudnia 2022 roku, PGNiG, Aktualności [online], 15 XI 2019 [dostęp: 17 VI 2020], dostępny w internecie: <http://pgnig.pl/aktualnosci/-/news-list/id/oswiadczenie-woli-zakonczeniakontraktu-jamalskiego-z-dniem-31-grudnia-2022-roku/newsGroupId/10184? changeYear $=2019$ \& currentPage $=3>$.

PGNiG ma już 31 koncesji na Norweskim Szelfie Kontynentalnym, PGNiG, Aktualności [online], 5 V 2020 [dostęp: 17 VI 2020], dostępny w internecie: 〈http://pgnig.pl/aktualnosci/-/news-list/id/pgnig-ma-juz-31-koncesji-na-norweskim-szelfie-kontynentalnym/newsGroupId/10184>.

PGNiG otrzymał 1,5 mld dolarów od Gazpromu, wGospodarce.pl [online], 30 vi 2020 [dostęp: 1 VII 2020], dostępny w internecie: <https://wgospodarce.pl/informacje/ 81741-pgnig-otrzymal-15-mld-dolarow-od-gazpromu $\rangle$.

Podraza A., Promocja demokracji a bezpieczeństwo europejskie: skuteczność i dylematy polityki wschodniej Unii Europejskiej w XXI w., „Politeja” 2016, nr 2 (41).

Podraza A., Stosunki polityczne i gospodarcze Wspólnoty Europejskiej z państwami Europy Środkowej i Wschodniej, Redakcja Wydawnictw Katolickiego Uniwersytetu Lubelskiego, Lublin 1996.

Premier Morawiecki w Hamburgu o Nord Stream 2 i armii UE, Deutsche Welle [online], 17 XI 2018 [dostęp: 15 IV 2020], dostępny w internecie: <https://www.dw.com/ $\mathrm{pl} /$ premier-morawiecki-w-hamburgu-o-nord-stream-2-i-armii-ue/a-46340361>. Prezes Pis: Międzymorze ma równoważyć układ $w$ Europie, gospodarkamorska.pl [online], 14 XI 2017 [dostęp: 20 VI 2020], dostępny w internecie: <https://www. gospodarkamorska.pl/Administracja,Prawo/prezes-pis:-miedzymorze-marownowazyc-uklad-w-europie.html $>$.

"Przepraszam, ale jak to działa?" Trump krytykuje Niemcy za kupowanie energii od Rosji, TVN24 [online], 21 VI 2020 [dostęp: 22 VI 2020], dostępny w internecie: <https://tvn24.pl/swiat/usa-donald-trump-o-nord-stream-2-krytykujeniemcy-za-kupowanie-energii-od-rosji-4616318>.

Putin strongly backed in controversial Russian reform vote, BBC News [online], 2 VII 2020 [dostęp: 3 VII 2020], dostępny w internecie: <https://www.bbc.com/ news/world-europe-53255964>.

Q\&A: What is a gas trading hub, and how are they established?, Reuters [online], 29 XII 2017 [dostęp: 15 V 2020], dostępny w internecie: <https://www.reuters.com/ article/us-china-gas-exchange-q-a/qa-what-is-a-gas-trading-hub-and-how-arethey-established-idUSKBN1ENOI1>.

Raabe S., The dispute over the Baltic Gas Pipeline. A threat or a necessary supply project?, Konrad-Adenauer-Stiftung, „Auslandsinformationen” 2009, issue 2.

Rada Ministrów, Strategia na rzecz Odpowiedzialnego Rozwoju do roku 2020 (z perspektywą do 2030 r.), Warszawa 2017. 
Rosicki R., Rosicki G., Znaczenie gazociąu nord Stream dla Polski, „Przegląd Bezpieczeństwa Wewnętrznego" 2012, t. 4, nr 6.

Rozporządzenie Rady Ministrów z dnia 24 kwietnia 2017 r. w sprawie minimalnego poziomu dywersyfikacji dostaw gazu ziemnego z zagranicy, Dz. U. z 2017 poz. 902 z dnia 9 maja 2017 r.

Ruszel M., Analiza wybranych nieformalnych sposobów wplywania na politykę energetyczna UE - na przykładzie Federacji Rosyjskiej, „Bezpieczeństwo Narodowe” 2015, nr 35.

Speech by Federal Chancellor Dr Angela Merkel on 16 February 2019 at the 55th Munich Security Conference, 16 II 2019 [dostęp: 12 VI 2020], dostępny w internecie <https:// www.bundesregierung.de/breg-en/news/speech-by-federal-chancellor-dr-angelamerkel-on-16-february-2019-at-the-55th-munich-security-conference-1582318>.

Stedman S. J., Spoiler problems in peace processes, "International Security” 1997, vol. 22, issue 2 .

Techau J., The foreign policy of Germany: economic giant, foreign policy dwarf?, [w:] Europe and America. The end of the transatlantic relationship?, ed. F. Bindi, Brookings Institution Press, Washington DC 2019.

Thomann P.-E., The Three Seas Initiative, a new project at the heart of European and global geopolitical rivalries, „Rocznik Instytutu Europy Środkowo-Wschodniej” 2019, t. 17 .

Three Seas Initiative: Trump in Warsaw supports the project, Visegrad Post [online], 8 VII 2017 [dostęp: 15 V 2020], dostępny w internecie: <https://visegradpost.com/ en/2017/o7/o8/three-seas-initiative-trump-in-warsaw-supports-the-project/ $>$.

Wigell M., Vihma A., Geopolitics versus geoeconomics: the case of Russia's geostrategy and its effects on the EU, "International Affairs" 2016, vol. 92, issue 3.

Wilczek P., Wspótpraca polsko-amerykańska w latach 2016-2020. Fakty $i$ liczby, "The Warsaw Institute Review" [online], 15 VI 2020 [dostęp: 4 VII 2020], dostępny w internecie: 〈https://warsawinstitute.review/pl/aktualnosci/wspolpraca-polsko-amerykanska-w-latach-2016-2020/>.

Wspólna deklaracja w sprawie Inicjatywy Trójmorza, 25 VIII 2016, dostępny w internecie [dostęp: 19 VI 2020]: 〈https:/www.prezydent.pl/aktualnosci/wizyty-zagraniczne/art,105,wspolna-deklaracja-w-sprawie-inicjatywy-trojmorza.html $>$.

Xunpenga S., Variam H. M.P., Key elements for functioning gas hubs: A case study of East Asia, „Natural Gas Industry B” 2018, vol. 5, issue 2.

Yermakov V., Sobczak K., Russia-Poland gas relationship: risks and uncertainties of the ever after, The Oxford Institute for Energy Studies, 2020 (Energy Insight, 70), s. 11-14.

Zwycięstwo PGNiG: Trybunał Arbitrażowy w Sztokholmie orzekt niższa cenę gazu od Gazpromu dla PGNiG, PGNiG, Aktualności [online], 30 III 2020 [dostęp: 17 VI 2020], dostępny w internecie: <http://pgnig.pl/aktualnosci/-/news-list/id/ zwyciestwo-pgnig-trybunal-arbitrazowy-w-sztokholmie-orzekl-nizsza-cene-gazuod-gazpromu-dla-pgnig/newsGroupId/10184?change-Year $=2020$ \& currentPage $=5>$. 